\title{
LANDSCAPE SERVICES OF HOMEGARDEN FOR RURAL HOUSEHOLD: A CASE STUDY OF JENGGOLO VILLAGE MALANG REGENCY
}

\author{
EuisElih Nurlaelih ${ }^{1 *}$, Luchman Hakim $^{2}$, Arief Rachmansyah ${ }^{3}$, Antariksa $^{4}$ \\ ${ }^{1}$ Doctoral Program in Environmental Sciences, Brawijaya University, Malang, Indonesia \\ 2 Department of Biology, Faculty of Mathematics and Natural Sciences, University of Brawijaya, Malang \\ ${ }^{3}$ Department of Civil Engineering, Faculty of Engineering, Brawijaya University, Malang, Indonesia \\ ${ }^{4}$ Department of Architecture, Faculty of Engineering, Brawijaya University, Malang, Indonesia \\ *corresponding author: euis.fp@ub.ac.id
}

\begin{abstract}
The homegarden is a micro-scale landscape where interactions between humans and their environment intensively. One form of interaction is in the form of benefits provided by the homegarden in the form of ecosystem services. This study aims to explore the landscape services of the homegarden in Jenggolo Village, which are one of the villages that is part of a rice barn in Malang Regency. Data were collected by observation and semi-structured interviews. The results of the study indicate that the homegarden provides complete ecosystem services including provisioningservices, regulation services, and cultureservices. Provisioning services for food and cultural services are important homegarden services for the household of Jenggolo Village, the majority of whom work as farmers and still cling to Javanese traditional culture. Awareness of the community towards the ecosystem services is one of the bases in determining a strategy for managing sustainable landscapes appropriately.
\end{abstract}

Keywords: Ecosystem Services, Landscape Services, Cultural Services, Homegarden

http://dx.doi.org/10.21776/ub.agrise.2019.019.3.2

Received 23 May 2019

Accepted 27 July 2019

Available online 25 August 2019

\section{INTRODUCTION}

Rural landscapes are characterized by the availability of extensive green open spaces in the form of agricultural land, gardens and, homegardens. The homegarden is area or open space that is directly adjacent to the house. The homegarden is managed by the family or household owner (Mazarolli, 2011). The homegarden for the village community has a very important role. The diversity of elements in the homegarden in the form of agroforestry can increase people's income by providing socio-economic and agro-ecological services (Linger, 2014). The homegarden can be a very useful strategy to increase the income of poor families, access to land and water, financial security, wages, nutrition, social status and, political status, and improve access to basic infrastructure (Mitchell \&Hanstad, 2004). The homegarden is part of a larger agricultural system (Bargali, 2016). Therefore, the sustainability of the homegarden is maintained so that it can always provide ecological services or ecosystem services so that it can increase the income of rural communities (Mayori, 2009; Pihatini et al., 2018). The homegarden is an important topic in landscape research because of its intersexual contribution to the conservation of plant diversity and household or family livelihoods (Berkowitz \& Medley, 2017).

Ecosystem services are defined as benefits derived from humans from ecosystems (MEA, 2005; Boyd and Barbier in Fisher, 2009). Ecosystem services can be grouped into 4 (four) categories, 
namely provisioning service, regulating service, cultural service, and supporting services (MEA, 2005). The classification of ecosystem services associated with landscapes is grouped into 5 (five) categories, namely: regulatory services, habitat services, provision services, information services and carrier services (De Groot, 2006). The simpler theory divides ecosystem services into 3 (three) categories, namely service provision, regulatory services or cultural services and arrangements (Hein et al. (2006). This study in its discussion is more detailed in explaining cultural landscape services. Scope of landscape cultural services include: recreation, aesthetics, education, science, cultural inspiration, art, design, cultural heritage, sense of place, spiritual and religious inspiration, and social relations (de Groot et al., 2010; Plieninger et al., 2013; De Agar et al., 2016) Grouping landscape cultural services based on the dimensions of human well-being includes daily activities, regulation of spatial structure, pleasure, health, personal satisfaction and social satisfaction (Valles-Planells et al., 2014).

Ecosystem services from the perspective of landscape architecture view the homegarden as a space of life that provides both physical, psychological and social benefits (Soga et al., 2017). The homegarden provides ecosystem services in the form of health and family welfare (Bargali, 2016). Interesting research on the function of the homegarden for immigrants found that the homegarden has benefits as a religious space for meditation and socialization; the homegarden is a cultural space where the elements become traditional food, medicine, and identity; homegardens are ecological spaces that connect with past landscapes while building relationships with new places; the homegarden is a family's memory space to remember family members so that it strengthens relationships between generations (Mazumdar\&Mazumdar, 2012). Structural and multifunctional complexity of the homegarden allows the provision of different benefits for ecosystems and humans (Galluzzi et al., 2010).

\section{RESEARCH METHODS}

The study was conducted in Jenggolo Village, Malang Regency, East Java. A qualitative method is through observations and interviews. Observations are made to observe the activities of the family of the homegarden owner in utilizing his homegarden in daily life. Whereas semi-structured interviews were carried out to respondents to obtain information about the perceptions and benefits obtained from the family from the homegarden. Respondents involved in this study consisted of 68 homegardens owners who were randomly selected regardless of gender, age, and education. Then the data is analyzed by cross-checking the respondents and the results of field observations systematically narrated. The results of the interviews were analyzed using simple statistics which were calculated as the percentage of respondents' answers.

\section{RESULTS AND DISCUSSION}

Jenggolo village is one of the agriculture villages in Malang Regency which has a characteristic of lowland with the main commodity of rice. Most of the villagers work as farmers. Almost all houses in this village have a homegarden even though with an area of less than $10 \mathrm{~m} 2$. Overall the area of land studied has an average area of $81.9 \mathrm{~m}^{2}$. The homegarden provides complete ecosystem services including supply services, regulatory services and, cultural services. Ecosystem services, in this case, are identical to landscape services (Hein et al., 2006). Ecosystem services tend to see the homegarden as an ecosystem along with biotic and abiotic elements in it, while the landscape architecture approach views the homegarden as a living space beside its elements. The results of the interviews showed that as many as $44.4 \%$ of respondents said the homegarden was very useful, while $55.6 \%$ said it was quite useful. Perceptions of homegarden ecosystem services can affect the sustainability of the homegarden. There is a positive relationship between people's perceptions of the ecosystem services with the diversity of types of plants in the homegarden (Dwiyono, 2004).

\section{Provisioning Services}

The Jenggolo Village homegarden is dominated by soft elements in the form of plants. The plant community in the homegarden with a multi-species planting system often forms multi-strata (Hakim, 2014). There are 146 species of plants consisting of 52 species of trees, 80 species of shrubs or herbs and 14 types of ground cover. Each of these plants provides benefits such as food sources, social is culture (ritual, aesthetic), and environment (shade, windbreak) (Figure 1). 


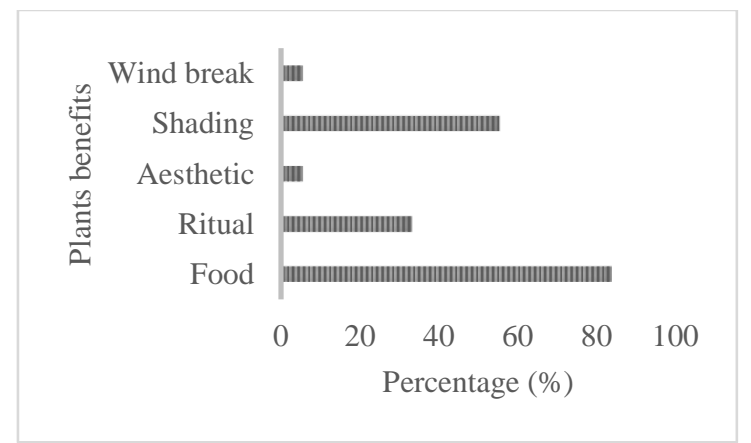

Figure 1. Benefits of plants in Jenggolo homegarden

It is known that the greatest benefits given by plants are food as a daily food ingredient and ingredients for medicines. This is in accordance with the types of plants that exist in the homegarden of Jenggolo Village which is overgrown with fruits, tubers and, Medicinal plants. Plants in the homegarden are generally planted for personal consumption as food, medicine, ceremonies and construction (Mazarolli, 2011). Plants in the homegarden play an important role in human daily life as food, traditional medical ingredients, economical and ornamental (Swandayani et al., 2016). Thus the homegarden plays an important role in providing food resources for local communities (Hakim, 2014; Berkowitz \& Medley, 2017) and is an alternative agroecosystem to meet family needs (Ortiz-Sanchez et al., 2015).

Table 1 shows the contribution of plants in the homegarden to family income based on the respondent's livelihood. The homegarden provides the biggest contribution to the farmer's family because farmers make the homegarden side cultivation after the mainland. The plants planted are generally plants that can be consumed both for daily food and medicine. Research in Bangladesh shows that homegardens can contribute an average of up to $52 \%$ of smallholder household income (Ali, 2005). As for the entrepreneurial livelihood, the homegarden contributes very little. This is because they feel they do not have enough time and knowledge to utilize the homegarden as cultivation land, so they tend to use the homegarden for other functions such as pavement for vehicle garages. But no matter how small the contribution of the homegarden to the community, well-managed homegardens can improve the livelihoods and quality of life of the community, reduce poverty, and encourage economic growth into the future in a sustainable manner (Maroyi, 2009).

Table 1. Percentage of contributions of homegarden plants to fulfill family needs in accordance with the livelihood

\begin{tabular}{|c|c|c|c|c|}
\hline \multirow{2}{*}{ Livelihood } & \multicolumn{2}{|c|}{$\begin{array}{c}\text { Contributions of } \\
\text { homegarden plants (IDR) }\end{array}$} & \multirow{2}{*}{$\begin{array}{c}\text { Jumlah } \\
\text { (IDR) }\end{array}$} & \multirow{2}{*}{$\begin{array}{c}\text { Percentage of } \\
\text { contribution of } \\
\text { homegarden to income } \\
(\%)\end{array}$} \\
\hline & Food & Health & & \\
\hline Farmer & 300 & 50 & 350 & 35,00 \\
\hline Small-medium entrepreneurs & 150 & 50 & 200 & 10,00 \\
\hline Mason \& woodworker & 150 & 50 & 200 & 13.33 \\
\hline Artist & 150 & 50 & 50 & 5,00 \\
\hline Entrepreneur & - & 50 & 50 & 2,00 \\
\hline
\end{tabular}

Source: Syafitriet al., 2014

In addition to the crops, respondents also exchanged seeds or seeds for each other. The survey results showed that $55.56 \%$ of plant seeds were obtained from other people, $16.67 \%$ were government assistance, $16.67 \%$ were self-growing and $5.55 \%$ were exchanged with neighbors. But in general, as many as $66.67 \%$ of seeds are obtained by buying. Seed exchange between neighbors is basically an exchange of material and knowledge. This exchange can indirectly maintain agrobiodiversity and cultural heritage from one generation to the next (Sthapit et al., 2006). The diversity of plants in the homegarden plays an important role in the conservation of biodiversity (Albuquerque et al., 2005; Sahoo et al., 2010; Caballero-Serrano et al., 2016; Bargali, 2016). Traditional gardens are sites for biodiversity management and conservation (Devi \& Das, 2010). The homegarden shows species diversity and the diversity of production systems which are key aspects in determining ecological sustainability (Bargali, 2016). 


\section{Regulatory Services}

The next benefit is the ecological benefits of plant elements in the garden as shade. Plants that function as shade are tree-shaped plants. The shade trees that grow mostly in the homegarden of Jenggolo Village include Mango (Mangifera indica L.), Rambutan (Nephelium lappaceum L.) and Guava (Psidium guajava $\mathrm{L}$.). These plants are sufficient to meet the requirements as shade plants, which are easy to grow on dense soils, do not have large roots on the ground, are resistant to strong gusts of wind, branches and twigs are not easily broken, do not fall easily, litter is produced little, quite calm, but not too dark, has no allelopathic substances, and has aesthetic value (Department of Forestry, 1992). This benefit includes one of the homegarden regulation services, namely the ability of ecosystems to regulate climate (Hein et al., 2006). Each tree is able to transmit 400 liters of water/day through evapotranspiration so that it has a cold effect on the environment (Gray \&Deneke, 1978).

The homegarden as a form of Green Open Space in rural areas has an important role in the absorption of carbon dioxide and producing oxygen through photosynthesis. The role of plants in an ecosystem is related to the regulation of the balance of carbon dioxide and oxygen in the air, regulation of soil water management, improvement of physical, chemical and biological properties of the soil, and others. The multi-layered canopy configuration and high genetic diversity make the homegarden ecosystem very efficient in utilizing space, energy, soil nutrition, and water (Jose \&Shanmugaratnam, 1993). Figure 2 shows multi-layered canopy configuration in West Java Indonesia (Prasetya, 2007). The homegarden also provides an ideal environment for wildlife species such as birds, mammals, reptiles, and insects, recycling of nutrients, reduction of soil erosion, and increased pollination (Galhena et al., 2013).

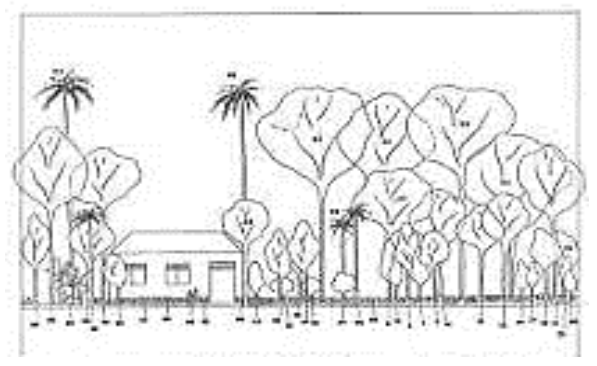

Figure 2. Model of multi-layered canopy configuration in West Java Indonesia

(Prasetya, 2007)
Plants are an important part of the water cycle where plants move water from the soil into the atmosphere through the process of transpiration. While rainwater does not directly fall to the ground because it is held by a tree canopy (throughfall) then flows through the stem (stemflow) and is absorbed into the soil (infiltration) into the subsurface flow (sub-surface runoff) or stored in the soil into groundwater (groundwater storage). The planted homegarden causes the land to remain permeable so that it effectively plays a role in maintaining the local hydrological system (Mazarolli, 2011). Homegarden land has good quality for transportation of air, heat, water and, solutes (FloresDelgadillo et al., 2011). Thus in the homegarden, various important ecological processes take place where the ecological processes in the homegarden will affect the larger ecosystem.

\section{Cultural Services}

The important benefits of plants for other Jenggolo Village people are as a complement to cultural and religious rituals. Through food, medicinal plants, religious or ceremonial plants in the homegarden, families, and communities can develop and maintain cultural traditions (Mazarolli, 2011). The plants most often used include Cananga (Cananga odorata var fructicosa Hook. F. \& Thomson). Therefore, Canangais widely planted in the homegarden of Jenggolo Village. Naturally, this plant is a type of tree that can reach a height of $10 \mathrm{~m}$. But the Cananga plants in the Jenggolo Village homegarden are maintained at a maximum height of 2-3 meters by pruning to facilitate the taking of flowers. This plant has high adaptability to various environmental conditions. Cananga can grow on all types of soil but does not like shallow water and shallow groundwater (Djazuli, 2005).

Based on its utilization, most of the respondents use the plants from the homegarden to meet their own family needs $(94.44 \%)$. Plants can also function as a means of socialization where as many as $61.11 \%$ of respondents make plants in the homegarden as a means to establish communication and togetherness in the community. Only a small percentage of respondents sell the produce from their plants (16.67\%). Respondents not only shared seeds or crops, but also shared information about how to grow, maintain and process the results. Exchange of homegarden products between households and relatives strengthens family 
relations (Maroyi, 2009). Interactions like this are very important for social integration and building social capital (Galhena et al., 2013; Linger, 2014).

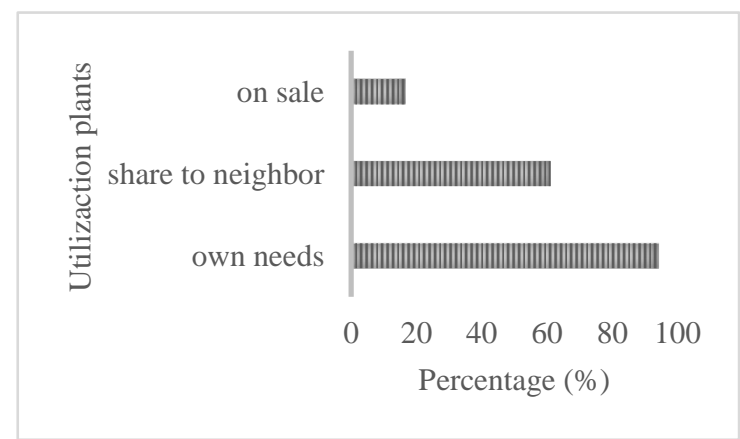

Figure 3. Utilization of homegarden plants in Jenggolo Village

Homegarden culture services are shown in Figure 4 and its description shown in Table 3 which consists of daily activities, regulation of spatial structures, health, pleasure, personal and social satisfaction. This approach is mainly based on grounds as cultural space and services that are associated with dimensions of human well-being (Valles-Planells et al., 2014).

The most important yard culture services are for daily activities including drying rice, as a place of work, for example, farmers drying rice, raising livestock, selling, workshops, and doing carpentry work.

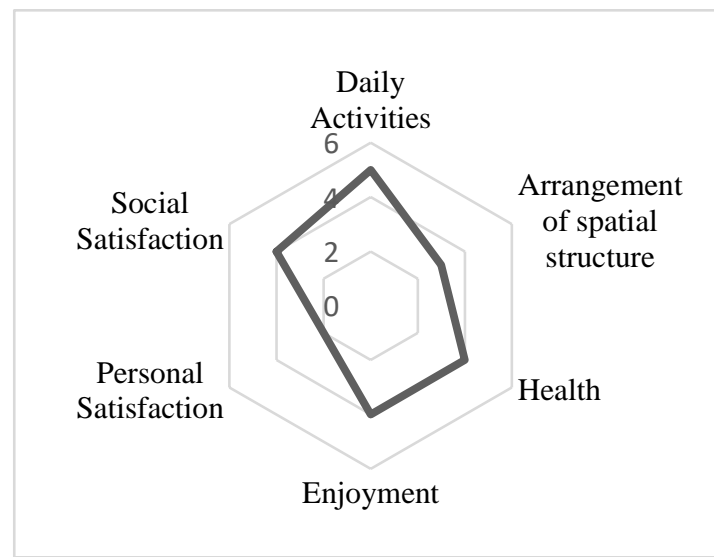

Figure 4. Culture services of homegardenin human welfare dimensions

Table 3. Description of culture services of homegardenin human welfare dimensions

\begin{tabular}{|c|c|c|c|}
\hline No & Cultural Services & & Description \\
\hline \multirow[t]{3}{*}{1} & Daily activities & 1 & $\begin{array}{l}\text { The homegarden is used by the family as part of a family } \\
\text { residence. }\end{array}$ \\
\hline & & 2 & $\begin{array}{l}\text { Some communities use the homegarden as a place of work, for } \\
\text { example, farmers drying rice, raising livestock, selling, } \\
\text { workshops, and doing carpentry work. }\end{array}$ \\
\hline & & 3 & $\begin{array}{l}\text { The homegarden is used by family members to move, moving } \\
\text { from house to cage, to wells and other cluster sections. }\end{array}$ \\
\hline \multirow[t]{3}{*}{2} & $\begin{array}{l}\text { Arrangement of } \\
\text { spatial structure }\end{array}$ & 4 & $\begin{array}{l}\text { In the homegarden, there is a circulation that connects between } \\
\text { zones in the cluster of residence. However, the circulation, in } \\
\text { general, is not specifically made either symbolically or } \\
\text { physically, for example, a footpath. In the homegarden, there is } \\
\text { also access to the exit cluster or vice versa. }\end{array}$ \\
\hline & & 5 & $\begin{array}{l}\text { The homegarden is useful as a buffer or house barrier from } \\
\text { outside disturbances such as the entry of livestock. The } \\
\text { homegarden is also useful for maintaining the privacy of the } \\
\text { owner's family. }\end{array}$ \\
\hline & & 6 & $\begin{array}{l}\text { The homegarden does not yet function as a provision of spatial } \\
\text { complexity }\end{array}$ \\
\hline 3 & Health & 7 & $\begin{array}{l}\text { The homegarden in JenggoloVillage is still wide enough to carry } \\
\text { out sports activities to support physical health, but until now the } \\
\text { community has not used the homegarden as a means of family } \\
\text { sports. This is because adult family members are busy working, } \\
\text { while children or adolescents choose to use school fields or } \\
\text { public spaces for sports. }\end{array}$ \\
\hline
\end{tabular}




\begin{tabular}{|c|c|c|c|}
\hline No & Cultural Services & & Description \\
\hline & & 8 & $\begin{array}{l}\text { The homegarden is used by family members to rest after work by } \\
\text { sitting, chatting and chatting so that they can support mental } \\
\text { health. }\end{array}$ \\
\hline \multirow[t]{2}{*}{4} & Enjoyment & 9 & $\begin{array}{l}\text { Elements in the homegarden can provide pleasure for residents of } \\
\text { the house such as the presence of birds in trees, ornamental } \\
\text { plants, livestock, and so on }\end{array}$ \\
\hline & & 10 & The homegarden is used by children to play together \\
\hline \multirow[t]{5}{*}{5} & $\begin{array}{l}\text { Personal } \\
\text { satisfaction }\end{array}$ & 11 & $\begin{array}{l}\text { Like houses, the homegarden is part of the spatial orientation of } \\
\text { family members. The homegarden is a part of the residence } \\
\text { where someone has an attachment in it }\end{array}$ \\
\hline & & 12 & $\begin{array}{l}\text { The homegarden provides information for research on the } \\
\text { history, botany, ecology and so on }\end{array}$ \\
\hline & & 13 & $\begin{array}{l}\text { The homegarden can be a place to study various knowledge } \\
\text { related to plants, history, agroforestry, landscape architecture and } \\
\text { so on. }\end{array}$ \\
\hline & & 14 & $\begin{array}{l}\text { The homegarden can provide a spiritual experience for residents } \\
\text { of the house by admiring and grateful for God's creation in the } \\
\text { form of homegarden elements consisting of flora and fauna } \\
\text { created by Allah }\end{array}$ \\
\hline & & 15 & $\begin{array}{l}\text { The homegarden can be a source of inspiration and information } \\
\text { so that families get non-physical benefits such as recreation, } \\
\text { aesthetics, and comfort }\end{array}$ \\
\hline \multirow[t]{3}{*}{6} & Social satisfaction & 16 & $\begin{array}{l}\text { The homegarden can be a gathering place between family } \\
\text { members or between family members and neighbors. The } \\
\text { homegarden becomes a space for social interaction through joint } \\
\text { activities such as children's playgrounds, quarreling or other } \\
\text { social activities }\end{array}$ \\
\hline & & 17 & $\begin{array}{l}\text { Indirectly the character of the homegarden will shape the identity } \\
\text { of a community that is shown through the elements of the } \\
\text { homegarden and its arrangement }\end{array}$ \\
\hline & & 18 & $\begin{array}{l}\text { The homegarden, as well as, the house undergoes transformation } \\
\text { along with the dynamics in the family of the owner. Thus the } \\
\text { homegarden can reflect the life of the owner. }\end{array}$ \\
\hline
\end{tabular}

\footnotetext{
Notes:

$1=$ residence; $2=$ workplace; $3=$ place to move $; 4=$ spatial connection; $5=$ barriers to interference; $6=$ provision of spatial complexity; $7=$ physical health; $8=$ mental health; $9=$ passive pleasure; $10=$ active pleasure; $11=$ search for directions; $12=$ scientific resources; $13=$ didactic resources; $14=$ spiritual experience; $15=$ source of inspiration; $16=$ social interaction; $17=$ community identity; $18=$ a sense of continuity
}

Culture landscape services are more nonmaterial, where landscapes provide benefits for human health, pleasure and, satisfaction. The homegarden can provide ecosystem services that have a direct and positive impact on human wellbeing ((Caballero-Serrano et al., 2016). The space in the homegarden is used by the household to express his ideas about beauty, show existence, and prestige. Ornamental plants in the homegarden providing visual and aesthetic values that can give prestige to the owner's family (Neulinger et al., 2013). In addition, the homegarden is used for socializing, resting, playing and exercising. The arranged grounds can be associated with a garden, which is a fenced plot of land used for fun and excitement (Laurie, 1986; Bander, 1978) so that it can function as a recreational and tourist area (Linger, 2014; Hakim, 2014).Like gardening, the homegarden 
provide benefits of social, psychological, and personal enrichment (Nicklett et al., 2016). The homegarden can be a place for parents to educate children about awareness, sensitivity and, concern for the environment (Mazumdar\&Mazumdar, 2012). The homegarden is an important social and cultural space where knowledge related to agricultural practices is transmitted (Galluzzi et al., 2010).

\section{CONCLUSION}

Jenggolo village has a high potential of land where most of the houses still have a homegarden. Overall the area of land studied has an average area of 81.9 $\mathrm{m} 2$. With 146 plant species consisting of 52 species of trees, 80 species of shrubs or herbs and 14 types of land cover, this village homegarden provides complete ecosystem services including supply services, regulatory services and cultural services. Supply services obtained from plants, mostly in the form of food. The homegarden also potential to be an area of biodiversity conservation. While regulatory services, especially plantlike shade and wind barrier. Cultural services are an important homegarden service for the people of Jenggolo Village, the majority of whom work as farmers and still cling to traditional Javanese culture. Communities use the homegarden for various family activities such as recreation, sports, play, socialization and preservation of cultural heritage. Awareness of the community towards the landscape services can be one of the bases in determining a strategy for managing sustainable landscapes appropriately.

\section{REFERENCES}

Albuquerque, U.P., Andrade, L.H.C., Caballero, J. (2005). Structure and floristics of homegardens inNortheastern Brazil. Journal of Arid Environments 62 (2005) 491-506.

Ali, A.M.S. (2005). Homegardens in smallholder farming systems: examples from Bangladesh. Human Ecology, Vol. 33, No. 2, April 2005 (2005).

Bargali, K. (2016). Traditional homegardens as a sustainable ecosystem for maintenance of biodiversity: a case study from Kumaun Himalaya, India. J Biodiversity, 7(2): 88-100 (2016).
Berkowitz, B.N. \& Medley, K.E. (2017). Homegardenscapes as sustainable landscape management on St. Eustatius, Dutch Caribbean. Sustainability 2017, 9, 1310.

Caballero-Serrano, V., Onaindia, M., Alday, J.G., Caballero, D., Carrasco, J.C., McLaren, B., Amigo, J. (2016). Plant diversity and ecosystem services in Amazonian homegardens of Ecuador. Agriculture, Ecosystems and Environment 225 (2016) 116-125.

De Agar, P. M., Ortega, M., de Pablo, C.L. (2016) A procedure of landscape services assessment based on mosaics of patches and boundaries. Journal of Environmental Management 180 (2016) 214-227.

De Groot, R. S. (2006). Function-analysis and valuation as a tool to assess land use conflicts in planning for sustainable, multifunctional landscapes. Landscape and Urban Planning $75: 175-186$

De Groot, R.S., Alkemade, R., Braat, L., Hein, L., Willemen, L. (2010). Challenges integrating the concept of ecosystem services and values in landscape planning, management and decision making. Ecological Complexity 7: 260-271.

DepartemenKehutanan. 1992. Manual Kehutanan. Jakarta: DepartemenKehutananRepublik Indonesia.

Devi, N. L. \& Das, A.K. (2010). Plant species diversity in the traditional homegardens of Meitei community: a case study from Barak Valley, Assam. Journal of Tropical Agriculture 48 (1-2): 45-48, 2010.

Djazuli, M. (2005). Peningkatan produktivitas dan peluang pengembangan ylang-ylang di Indonesia. Perspektif. Volume 4 Nomor 2, Desember 2005: 64 - 70 .

Dwiyono, E. (2004). Persepsi masyarakat tentang layanan ekosistem dan struktur serta pengelolaan pekarangan di pedesaan Kecamatan Jatinangor Kabupaten Sumedang. Thesis. Universitas Padjadjaran. Bandung.

Fisher, B., Turner, R.K., Morling, P. (2009). Defining and classifying ecosystem services 
for decision making. Ecological Economics. 68(13):643-653.

Flores-Delgadillo, L., Fedick, S.L., SolleiroRebolledo, E., Palacios-Mayorga, S., OrtegaLarrocea, P., Sedov, S., Osuna-Ceja, E. (2011). A sustainable system of a traditional precision agriculture in a Maya homegarden: soil quality aspects. Soil \& Tillage Research. 113 (2011) 112-120.

Galhena, D.H., Freed, R., Maredia, K.M. (2013). Homegardens: a promising approach to enhance household food security and wellbeing. Agriculture \& Food Security 2013 2:8.

Galluzzi, G., Eyzaguirre, P., Negri V. (2010). Homegardens: neglected hotspots of agrobiodiversity and cultural diversity. BiodiversConserv (2010) 19:3635-3654.

Grey, G.W.\&Deneke, F.I. (1978). Urban forestry. John Wiley and Sons.

Hakim, Luchman. (2014). Etnobotani dan manajemen kebun pekarangan rumah: ketahananpangan, kesehatandanagrowisata. Selaras. Malang.

Hein, L., Koppen, K.V., De Groot, R.S., Ierland, V.E.C. (2006). Spatial scales, stakeholders and the valuation of ecosystem services. Ecological Economics 57(2): 209-228.

Jose, D. \&Shanmugaratnam, N. (1993). Traditional homegardens of Kerala: a sustainable human ecosystem. Agroforestry Systems 24: 203-213, 1993.

Laurie, M. 1986. An introduction to landscape architecture. New York: American Elsevier Publ. Co. Inc.

Linger, E. (2014). Agro-ecosystem and socioeconomic role of homegarden agroforestry in Jabithenan District, North-Western Ethiopia: implication for climate change adaptation. SpringerPlus 2014, 3:154.

Maroyi, A.(2009). Traditional homegardens and rural livelihoods in Nhema, Zimbabwe: a sustainable agroforestry system, International Journal of Sustainable Development \& World Ecology, 16:1, 1-8
Mazarolli, D.M. (2011). The benefits of tropical homegardens. The overstory \#239 the benefits of tropical homegardens. Permanent Agriculture Resources, Holualoa, Hawaii.

Mazumdar, S., \&Mazumdar, S. (2012). Immigrant homegardens: Places of religion, culture, ecology, and family. Landscape and Urban Planning. Volume 105, Issue 3, 15 April 2012, 258-265.

Millennium Ecosystem Assessment (MEA). (2005). Ecosystems and human well-being: multiscale assessment. Millennium Ecosystem Assessment Series 4. Washington DC: Island Press.

Mitchell, R., \& Hanstad, T. (2004). Small homegarden plots and sustainable livelihoods for the poor. Livelihood Support Programme (LSP) An inter-departmental programme for improving support for enhancing livelihoods of the rural poor. Rural Development Institute (RDI) USA. Food and Agriculture Organization of The United Nations.

Nicklett, EJ. Anderson, L.A., Yen, I.H. (2016). Gardening activities and physical health among older adults: a review of the evidence. J ApplGerontol. 2016 June; 35(6): 678-690.

Ortiz-Sánchez, A., Monroy-Ortiz, C., RomeroManzanares, A., Luna-Cavazos, M., CastilloEspaña, P. (2015). Ethnobotany multipurpose functions of homegardens for family subsistence. Botanical Sciences 93 (4): 791-806.

Prasetyo, B. 2007. Profil Vegetasi Pekarangan di Desa Jabon Mekar, Kecamatan Parung, Bogor. Jurnal Matematika, Sains, dan Teknologi, Volume 8, Nomor 1, Maret 2007, $17-30$.

Plieninger, T., Dijks, S., Oteros-Rozas, E., Bieling, C. (2013). Assessing, mapping, and quantifying cultural ecosystem services at community level. Land Use Policy 33:118129.

Sahoo, U. K., Rocky, P., Vanlalhriatpuia, K., Upadhyaya, K. (2010). Structural diversity and functional dynamism of traditional homegardens of North-East India. Bioscan: Special issue, Vol. 1;159-171; 2010. 
Soga, M., Gaston, K.J., Yamaura, Y.(2017). Gardening is beneficial for health: a metaanalysis. Preventive Medicine Reports 5 (2017) 92-99.

Sthapit, B.R., Gautam, R., Eyzaguirre, P. (2006). The value of homegardens to small farmers on Gautam, R., Sthapit, B.R., Shrestha, P.K. (eds.) (2006). Homegardens in Nepal: Proceeding of a workshop on "Enhancing the contribution of homegarden to on-farm management ofplant genetic resources and to improve the livelihoods of Nepalese farmers: Lessons learnedand policy implications", 6-7 August 2004, Pokhara, Nepal. LI-BIRD, Bioversity Internationaland SDC.
Swandayani, R.E., Hakim, L., Indriyani, S. (2016) Homegarden of Sasak people inSajang Village, Sembalun, East Lombok, Indonesia. International Journal of Research Studies in Agricultural Sciences (IJRSAS)Volume 2, Issue 1, January 2016, 32-40.

Syafitri, F.R., Sitawati, Setyobudi, L. (2014). Kajianetnobotanimasyarakatdesaberdasarkan kebutuhanhidup. Jurnal Protan Vol 2, No 2 (2014).

Vallés-Planells, M., Galiana F., Van Eetvelde, V. (2014). A classification of landscape services to support local landscape planning. Ecology and Society19(1): 44. 